\title{
АНТИКРИЗОВИЙ МЕНЕДЖМЕНТ ПІДВИЩЕННЯ КВАЛІФІКАЦІї
}

https://doi.org/10.37472/2707-305X-2020-2-1-7-9

\section{КАРТАШОВА \\ Любов Андріївна \\ доктор педагогічних наук, nрофресор, заступник директора Центрального інституту післядипломної освіти Державного закладу вищої освіти «Університет менеджменту освіти», Національна академія педагогічних наук України, м. Київ, Україна}

\section{КИРИЧЕНКО}

\section{Микола Олексійович} кандидат педагогічних наук, дочент, ректор Державного закладу вищої освіти "Університет менеджменту освіти», Начіональна академія педагогічних наук України, м. Київ, Україна

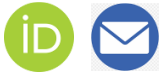

\section{СОРОЧАН}

Тамара Михайлівна доктор педагогічних наук, профресор, директор Центрального інституту післядипломної освіти Державного закладу вищої освіти "Університет менедженту освіти», Національна академія педагогічних наук України, м. Київ, Україна

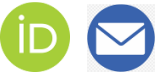

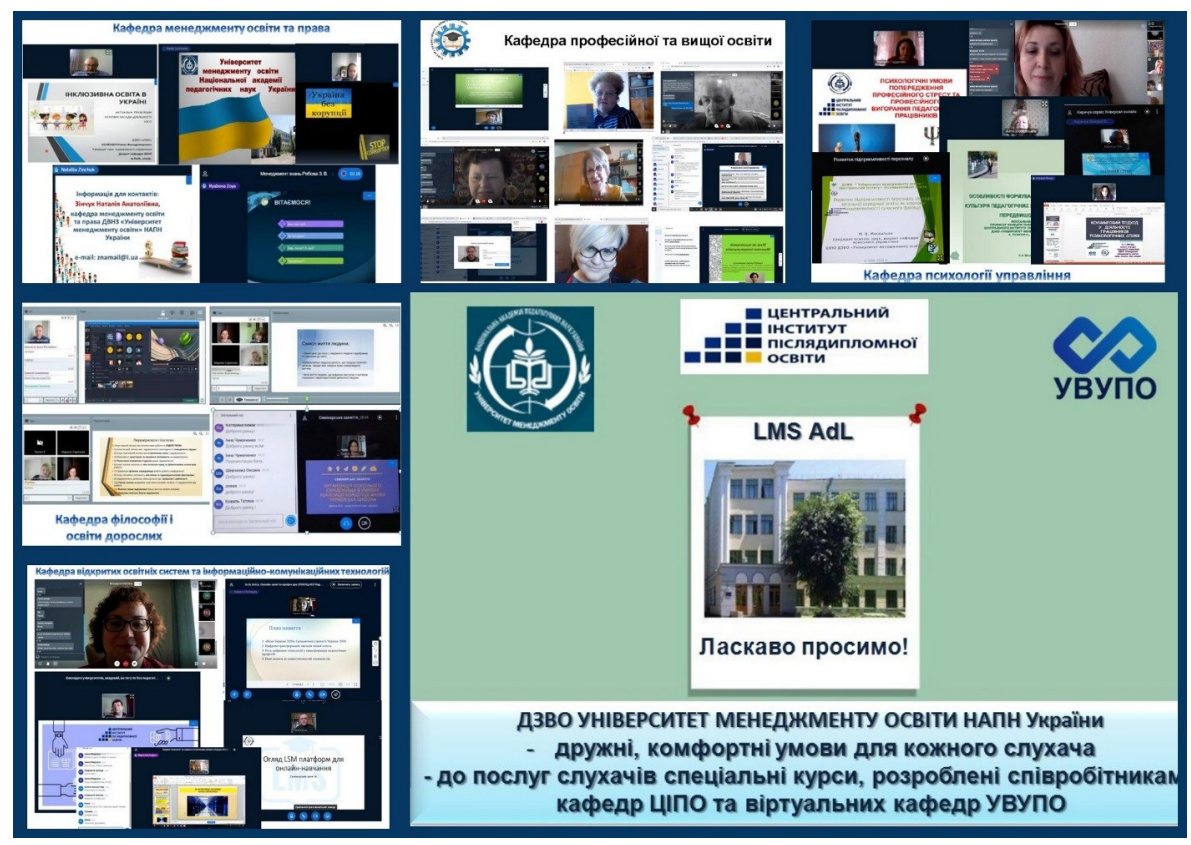

Анотачія. Стаття присвячена проблемі управління дистанційним навчанням слухачів курсів підвищення кваліфрікації у період кризи на прикладі досвіду освітньої діяльності Центрального інституту післядипломної освіти Державного закладу вищої освіти «Університет менеджмнту освіти» НАПН України. Криза характеризується як різка зміна стану речей, злам, загострення становища, критичне виявлення протиріч у соціальноекономічній системі або окремій організації, що загрожує їі стійкості в оточуючому середовищі й унеможливлює виконання функцій у звичайному режимі. Узагальнені особливості функиіонування системи підвищення кваліфікації в умовах кризи. Подано визначення антикризового менедженту як управління відповідною системою у стані дисбалансу. висвітлено практичний досвід діяльності з підвищення кваліфрікаиії педагогічних, науково-педагогічних і керівних кадрів освіти в період карантину, що склався в ЦІПО ДЗВО «УМО» НАПН України. Представлено антикризовий менеджмент системи неформальної освіти "Український відкритий університет післядипломної освіти», зокрема створення віртуальних кафедр, практику розроблення змісту освіти, зорієнтованого на актуальні запити споживачів, замовників та стейкхолдерів освітніх послуг з підвищення кваліфікації. Надані рекомендації щодо організації дистанційного навчання на курсах підвищення кваліфікації у період кризи.

Ключові слова: підвищення кваліфікації; дистанційне навчання; криза; антикризовий менеджмент; віртуальні кафедри.

Криза - це різка зміна стану речей, злам, загострення становища, критичне виявлення протиріч у соціально-економічній системі або окремій організації, що загрожує її стійкості в оточуючому середовищі й унеможливлює виконання функцій у звичайному режимі (Сорочан, 2009а; Сорочан, 2009b). 
Поширення пандемії у глобалізованому світі, безпрецедентні заходи з її подолання, визначені постановою Кабінету Міністрів України «Про запобігання поширенню на території України гострої респіраторної хвороби COVID-19, спричиненої коронавірусом SARS-CoV-2» від 11 березня 2020 р. № 211 (Кабінет Міністрів України, 2020) стали чинником кризового стану освіти в Україні. Загострилися протиріччя між вибором звичного способу життя населення і стратегією максимальної безпеки для здоров'я кожного громадянина країни і суспільства загалом.

Ситуація, що наразі генерує кризу, пов'язана з неможливістю швидкого реагування та подолання негативних впливів. Криза руйнує важливі закономірності, усталені зв'язки, традиційні схеми дій у системі освіти загалом, в окремому закладі й установі. Водночас кризу можна охарактеризувати як етап розвитку соціальноекономічної системи, необхідний для зняття напруження та усунення деформацій у ній (Сорочан, 2009a; Сорочан, 2009b).

В умовах кризи значно збільшується потреба у висококваліфікованих управлінських, педагогічних, науково-педагогічних кадрах, спроможних подолати кризу та її наслідки. Виникає проблема забезпечення стабільного функціонування системи підвищення кваліфікації в умовах кризи, управління нею, знаходження нових можливостей провадження освітнього процесу, наукової і методичної діяльності без зниження якості освіти. Саме тому важливим $є$ висвітлення управління підвищенням кваліфікації в умовах кризи на прикладі освітньої діяльності Центрального інституту післядипломної освіти ДЗВО «Університет менеджменту освіти» НАПН України (далі - ЦІПО ДзВО «УМО») та надання рекомендацій щодо організації дистанційного навчання.

Загальна неготовність до тривалого функціонування в умовах кризи системи освіти, закладів і установ усіх типів і рівнів підтверджується недостатністю публікацій і наукових досліджень за цією проблемою. Окремі положення, які можна застосувати у педагогіці, висвітлено в публікаціях економічного і соціологічного змісту. Зокрема, в роботах Р. Акоффа, Дж. Магидсона, Г. Эддисон (2007) акцент зроблено на попередженні та проєктуванні криз, М. Зубарєвої (2014) - на застосуванні антикризових PR-технологій, Р. Хіта (2002) - на поведінці керівників у період кризи. Також можна відзначити статті Т. Сорочан (2009а; 2009b), які розкривають особливості менеджмен-

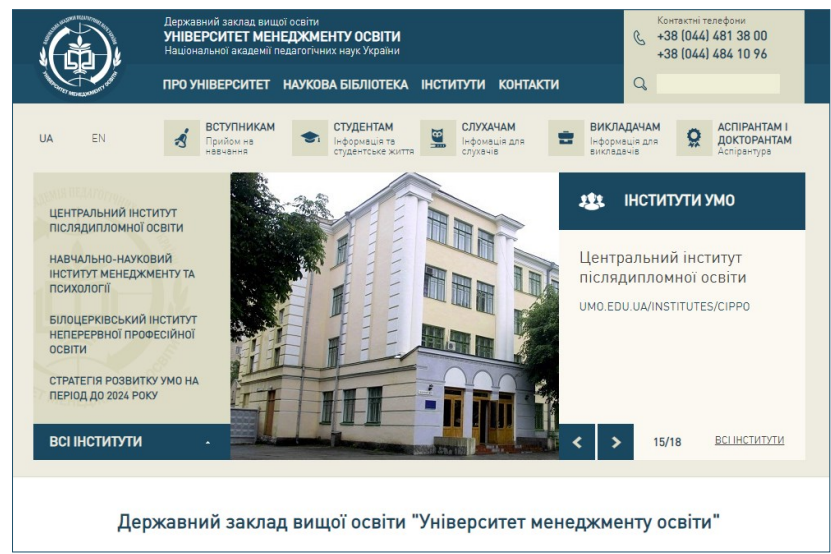

ту загальноосвітніх навчальних закладів у період економічної кризи 2008-2009 рр. Проте функціонування закладів освіти в той період істотно відрізнялося від нинішнього, оскільки вони продовжували роботу у звичному режимі.

Узагальнення спільних відомостей про кризу із різних галузей знань дає підстави констатувати наступне. Кризи класифікують за факторами виявлення, значущими показниками, параметрами функціонування системи - всіма ознаками, які засвідчують розбалансованість системи. Крім факторів, кризи відрізняються симптомами першими ознаками виникнення проблем, показниками найбільш уразливих сторін функціонування системи (Сорочан, 2009а; Сорочан, 2009b). Типологія криз віддзеркалює окремі сукупності економічних, соціальних, організаційних, психологічних, демографічних, екологічних факторів.

В організаційному устрої соціальноекономічної системи можуть загострюватись відношення, пов'язані із визначенням структури, підпорядкування, розподілом та інтеграцією видів діяльності, функцій, повноважень. Так виникають організаційні кризи. Їхні основні чинники: бюрократизація структур; конфлікти між

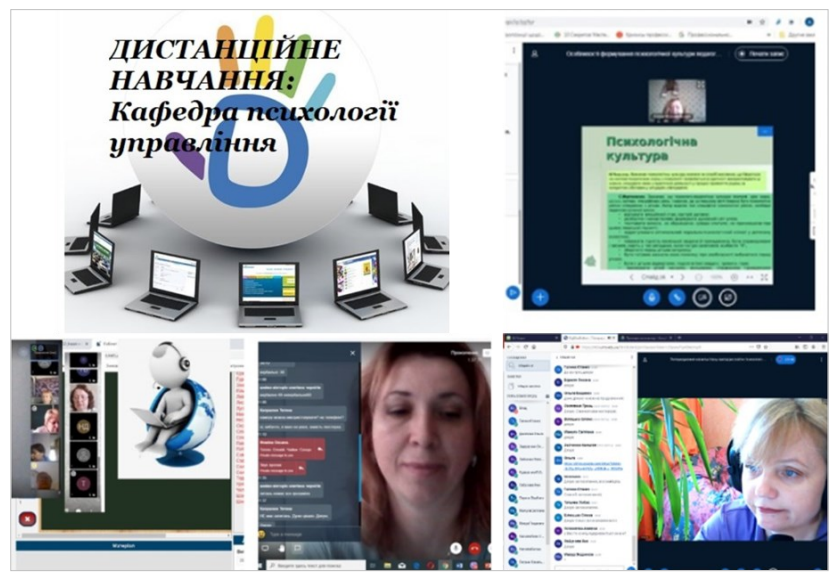

Кафедра психології управління ЦІПО ДЗВО «УМО» 
структурними підрозділами, менеджерами різних рівнів; безвідповідальність; втрата контролю; відтік ресурсів і погіршення фінансовогосподарської діяльності внаслідок помилок або непрофесіоналізму управлінців; розбалансованість усієї системи управління; порушення координації та інтеграції діяльності (Сорочан, 2009а; Сорочан, 2009b).

Незалежно від зовнішніх впливів, у самій організації також постійно виникають проблеми, які можуть призвести до кризи, що супроводжується різким погіршенням показників діяльності. Ознаки кризи, яка виникла в організації, подібні до загальних: виникнення конфліктів; переважне застосування застарілих методик і технологій; втрата конкурентних переваг; відтік ресурсів. Діагностування кризи в організації - це сукупність методів, спрямованих на виявлення проблем, слабких місць у системі управління. Діагностику також можна представити як оцінювання діяльності організації щодо загального управлінського впливу, визначення відхилень від заданих параметрів як характеристику можливостей організації щодо діяльності у швидко змінюваному середовищі (Сорочан, 2009а; Сорочан, 2009b).

Існування соціально-економічних систем $\epsilon$ циклічним процесом, тому спостерігається певна закономірність у настанні та подоланні криз. Суспільство, окрема організація, їі підсистема виявляють тенденції або функціонування (підтримання життєдіяльності, збереження функцій, цілісності системи та їі сутнісних характе- ристик), або розвитку (набуття нової якості, прогресивне реагування на нові умови середови ща, пов'язане зі змінами в предметі, умовах праці та в самій людині) (Сорочан, 2009а; Сорочан, 2009b). Криза в економіці та суспільному житті не може не позначитись на житті окремої організації. Отже, у цей період керівник має дещо змінити в управлінні освітньою організацією, щоб запобігти руйнівним наслідкам кризи.

Охарактеризуємо особливості функціонування системи підвищення кваліфікації в умовах кризи. До них ми відносимо такі:

- необов'язковість намірів суб'єктів підвищення кваліфікації;

- територіальну віддаленість суб'єктів підвищення кваліфікації;

- соціально-економічні ризики;

- перешкоди, пов'язані з умовами професійної діяльності слухачів;

- недоліки нормативно-правових актів 3 підвищення кваліфікації;

- неготовність керівників до управлінської діяльності в умовах кризи.

Заклади, організації і установи, де відбувається підвищення кваліфікації, мають змінний контингент здобувачів освіти - слухачів курсів підвищення кваліфікації. Це зумовлює певну необов'язковість намірів обох сторін. Слухачі вільно обирають заклад, установу, організацію для підвищення кваліфікації і так само вільно можуть змінити власні наміри. У свою чергу суб'єкти, що надають освітні послуги з підвищен-

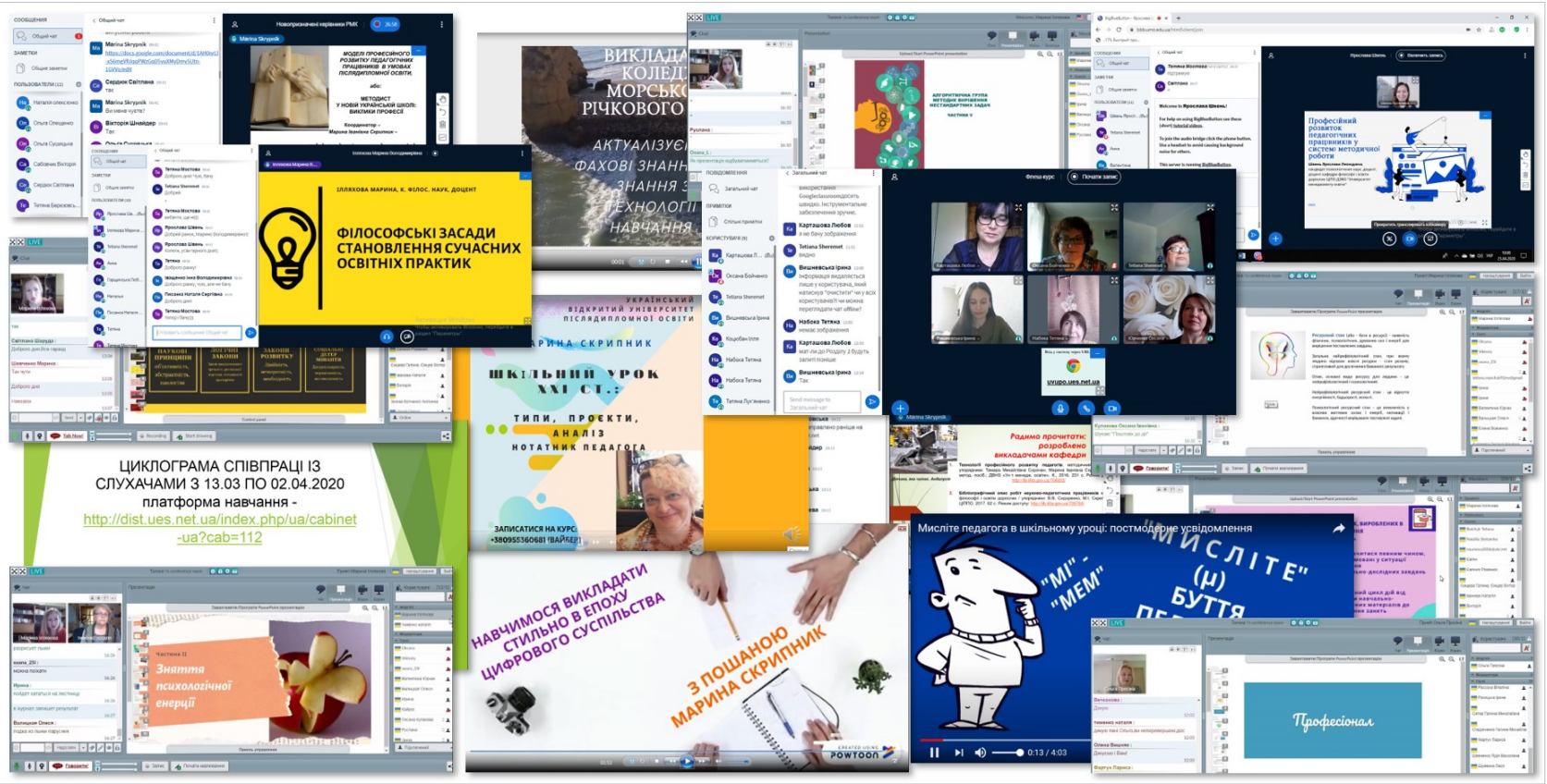

Кафедра філософії і освіти дорослих ЦІПО ДЗВО «УМО» 
ня кваліфікації, можуть під впливом кризи не отримати заплановане фінансування, власники можуть відмовити їм в оренді навчальних площ, також може бути обмеженим доступ до власної інфраструктури тощо. Такими факторами пояснюється перша особливість - необов'язковість намірів суб'єктів підвищення кваліфікації.

Наступна особливість зумовлена тим, що слухачі можуть проживати на значній відстані від місця проведення курсів підвищення кваліфікації. В умовах кризи пересування транспорту обмежене, що негативно позначається на можливості слухачів дістатися місця проведення навчання.

На здатність слухачів підвищувати кваліфікацію впливає загроза зниження або навіть невиплати заробітної плати, різка зміна і невизначеність режиму діяльності за основним місцем роботи.

Особливої уваги потребує аналіз нормативноправових актів державного рівня, а також юридичних осіб, що провадять освітню діяльність 3 підвищення кваліфікації. У більшості з них немає розділів, які унормовують дистанційне навчання, не приділено уваги регламентації діяльності організації загалом, структурних підрозділів, персоналу в умовах кризи. Це поглиблює невизначеність, яка $є$ ознакою будь-якої кризової ситуації.

Управлінська діяльність в умовах кризи також має певні відмінності. Збільшується значення комунікації між керівником, педагогами і споживачами освітніх послуг. Посилюється потреба в узгодженні цілей, рішень, дій, обговоренні результатів. Зростає кількість питань, які потребують роз'яснення, «ручного регулювання».

Ухвалення нестандартних рішень, увесь комплекс управлінських функцій у період кризи істотно відрізняється від менеджменту в стабільних умовах. Криза в перекладі з грецької означає «рішення», а ієрогліф, який позначає кризу, складається з двох частин: втрати та можливості розвитку, нової перспективи (Сорочан, 2009а; Сорочан, 2009b). Отже, наслідками кризи можуть бути або послідовна трансформація, оновлення організації, або різкі зміни та ії руйнація, виникнення нової кризи.

Правильне застосування технології антикризового менеджменту може забезпечити протидію негативним тенденціям, допомогти подолати кризу. І навпаки, бездіяльність, очікування того, що всі проблеми будуть розв'язуватись самі собою, може спровокувати значне погіршення наслідків кризи (Сорочан, 2009а; Сорочан, 2009b).

Антикризовий менеджмент - це управління системами у стані дисбалансу, що включає сукупність процедур, методів, прийомів, спрямованих на розпізнавання криз, їхню профілактику, створення умов для зниження негативного впливу та подолання наслідків (Сорочан, 2009а; Сорочан, 2009b).

Технологія антикризового менеджменту послідовність дій щодо реалізації механізму впливу на систему з метою попередження,

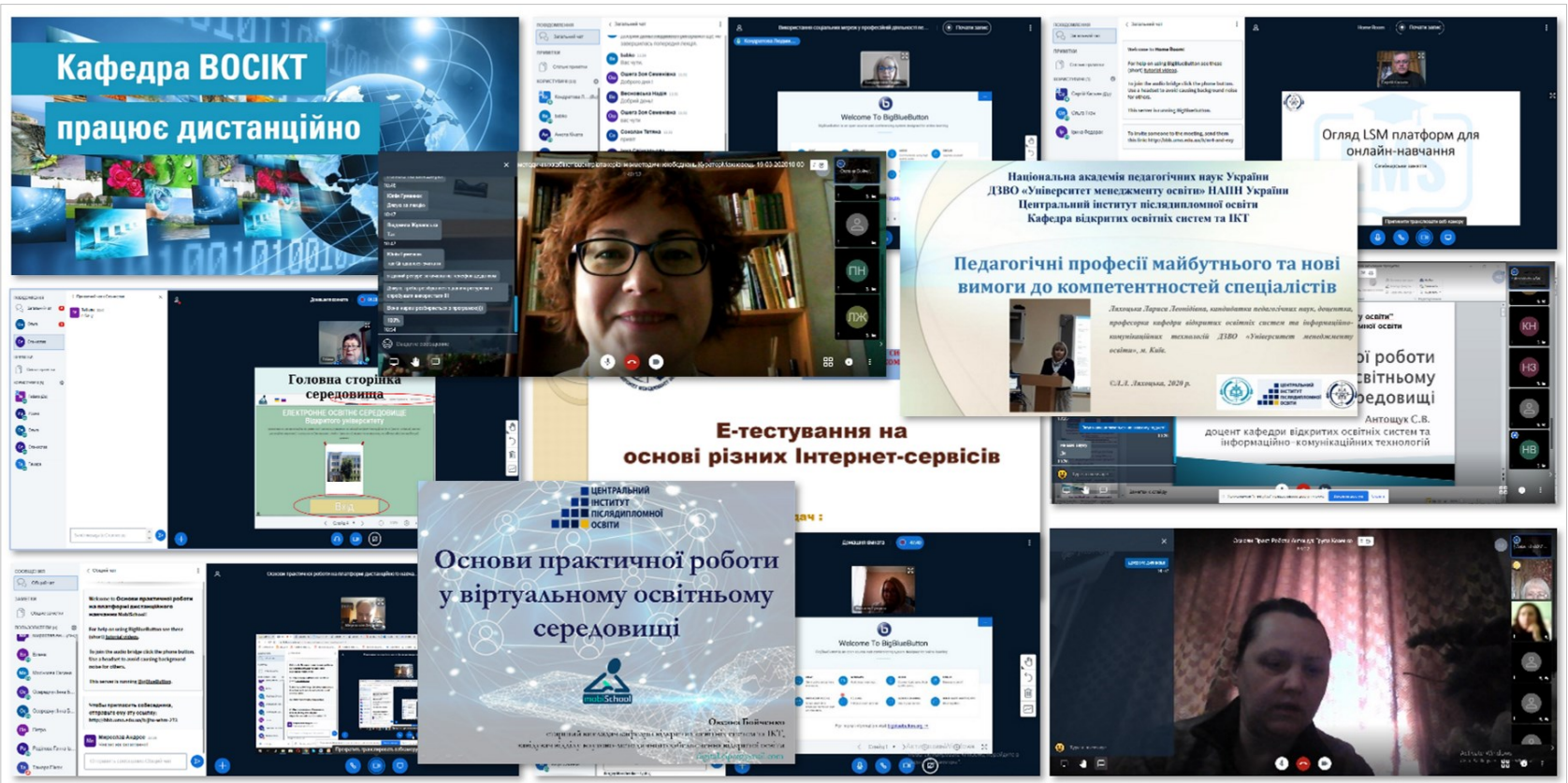

Кафедра відкритих освітніх систем та інформаційно-комунікаційних технологій ЦІПО ДзВО «УМО» 
послаблення або подолання криз різного типу (Сорочан, 2009а; Сорочан, 2009b).

Основними напрямами антикризового менеджменту на рівні освітньої організації $€$ постійний моніторинг ії̈ стану, розроблення нових управлінських, фінансових і маркетингових стратегій, посилення роботи з персоналом. В антикризовому менеджменті використовується комплекс методів з різних галузей: соціальні технології, економічний аналіз, прогнозування, розроблення інвестиційних проєктів, антикризових програм тощо. Антикризовий менеджмент ґрунтується на наукових знаннях та аналізі практичного досвіду щодо оптимізації механізмів регуляції систем, виявлення прихованих можливостей, потенціалу розвитку (Сорочан, 2009а; Сорочан, 2009b). Це потребує ухвалення складних управлінських рішень в умовах обмежених фінансових ресурсів, високого ступеня невизначеності та ризику. За таких умов посилюється необхідність діяти швидко, своєчасно, компетентно, відповідально.

Антикризовий менеджмент має комплексний, системний характер. Він спрямований на запобігання та подолання негативних для організації явищ сучасними засобами, розроблення та реалізацію відповідної стратегічної програми, яка дає можливість зберегти й навіть укріпити позиції за будь-яких обставин, спираючись в основному на власні ресурси (Сорочан, 2009а; Сорочан, 2009b).

Особливої уваги в антикризовому менеджменті потребують кадри. Перш за все, слід проаналізувати їхню здатність повноцінно виконувати власні функції, звернути увагу на мотивацію щодо протидії проявам кризи та подолання наслідків. Важливо посилити підтримку керівників структурних підрозділів, усіх, кому делеговані ті чи інші повноваження. Більш чіткою має стати постановка завдань перед членами колективу, більш конкретними - критерії оцінювання професійної діяльності. Одним із пріоритетів виходу з кризи $\epsilon$ орієнтація персоналу на навчання, опанування нових компетентностей, адже саме кваліфікований персонал забезпечує найважливішу передумову конкурентоспроможності освітньої організації (Сорочан, 2009а; Сорочан, 2009b). В антикризовому менеджменті подається така порада керівникові: більш ефективним є чітке визначення повноважень і завдань кожного працівника, ніж заохочення та покарання.

Під час кризи важливо посилити прозорість управління і на цій основі узгоджувати інтереси, виробляти пріоритети, координувати дії. Працівники мають розуміти перспективи, а керівники ухвалювати адекватні до ситуації рішення. Менеджери, спроможні показати колективу чіткі реалії та перспективи, частіше досягають результату ніж ті, які дотримуються командно-адміністративного стилю управління (Сорочан, 2009а; Сорочан, 2009b). Взаємодовіра сприяє підвищенню ефективності діяльності.

Найбільш поширеною помилкою менеджменту під час кризи є прагнення до масштабних ініціатив, тоді як фахівці у галузі економіки наполягають на тому, що чітке визначення меж відповіда-

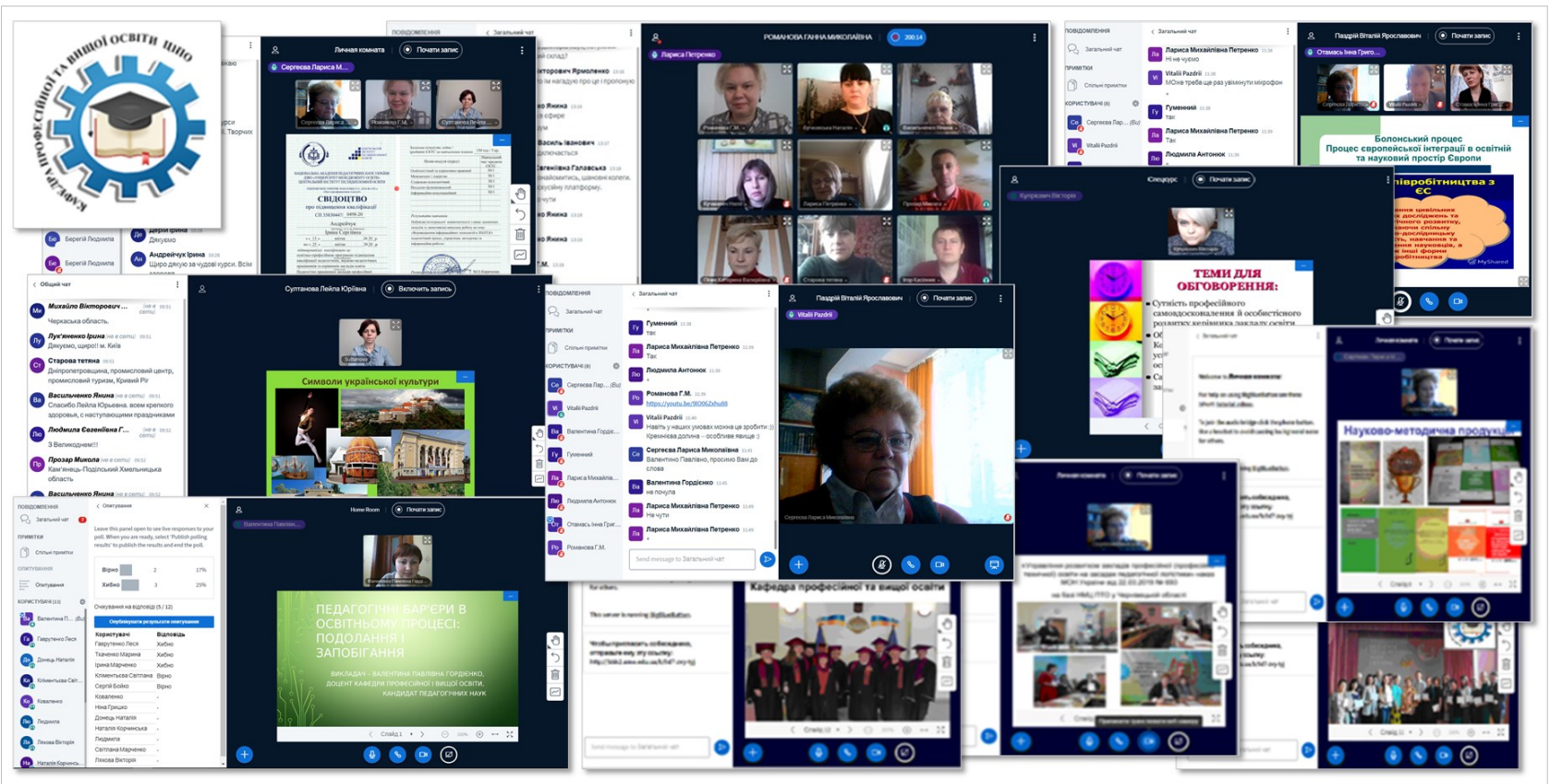

Кафедра професійної та вищої освіти ЦІПО ДЗВО «УМО» 
льності працівників, розуміння ними пріоритетів, цілей і завдань, посилення корпоративної культури є більш прийнятним шляхом до подолання кризи (Сорочан, 2009а; Сорочан, 2009b).

3 урахуванням зазначеного вище пропонується така технологія (послідовність дій) антикризового менедженту підвищення кваліфікації (Сорочан, 2009а; Сорочан, 2009b).

Перший етап можна охарактеризувати як пропедевтику кризи. Зважаючи на те, що кризи відбуваються циклічно, управління підвищенням кваліфікації має бути спрямоване на їхнє передбачення та формування готовності діяти в цих умовах. 3 цією метою менеджерами попередньо визначаються можливі негативні впливи соціального або внутрішнього середовища на процес підвищення кваліфікації, що можуть спричинити кризу, тобто неможливість суб'єкта виконувати свої функції.

Також до настання кризи має бути зроблений прогноз щодо можливої хронології кризових явищ. Це створює передумови для розроблення плану дій з запобігання проявам кризи, починаючи із заходів для протидії подіям, що прогнозуються першими.

Для пропедевтики кризи керівники всіх рівнів мають опрацювати нормативно-правові акти щодо юридичних, фінансових, кадрових, матеріально-технічних аспектів протидії різним проявам і наслідкам кризи. Слід приділити увагу внутрішнім нормативно-правовим актам організації, що надає освітні послуги з підвищення кваліфікації. В умовах реформування посилюється автономія закладів освіти, тому доцільно ввести окремі положення у внутрішні документи, що регламентують управлінську, освітню, наукову діяльність щодо особливостей виконання функцій кожним структурним підрозділом, кожним працівником в період кризи.

Другий етап антикризового менеджменту спрямований на реалізацію превентивних заходів, які дозволяють послабити наслідки майбутньої кризи. Менеджмент підвищення кваліфікації на цьому етапі має бути спрямований на розвиток компетентності персоналу, адже криза погіршує соціальне середовище, матеріальні та фінансові ресурси, а професіоналізм працівників не зменшується, а навпаки, сприяє ії̈ подоланню.

Превентивні заходи також передбачають врахування чинників, які погіршують стан педагогічної системи підвищення кваліфікації під час кризи, а саме:

- безвідповідальність;

- втрата контролю над окремими етапами освітнього процесу, окремими структурними підрозділами або над системою загалом;

- розбалансованість системи управління, зниження рівня планування, організації, координації діяльності окремих співробітників, структурних підрозділів або цілої системи;

- недостатня інформація або навмисне подання негативної інформації.

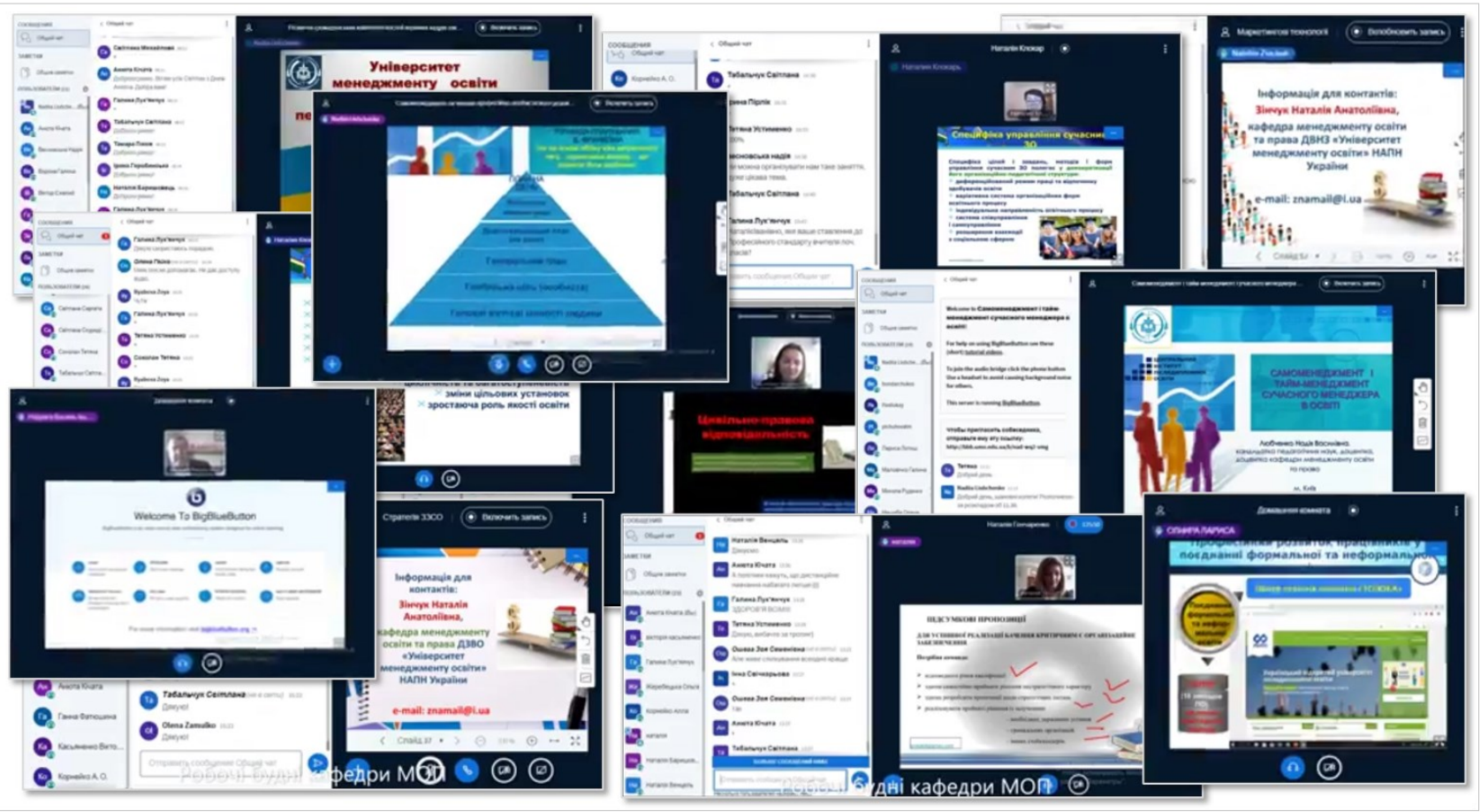

Каредра менеджменту освіти і права ЦІПО ДзВО «УМО» 
Спрямовувати зусилля на послаблення й усунення цих чинників менеджерам треба заздалегідь, оскільки при настанні кризи постають інші складні і невідкладні завдання.

Превентивна підготовка менеджменту до протидії кризі передбачає мобілізацію внутрішніх ресурсів організації і посилення ії конкурентних переваг.

Якщо пропедевтичний і превентивний етапи підготовки до управління підвищенням кваліфікації були проведені ефективно і дали результат, то кризовий період буде послабленим, без зривів виконання основних функцій організацією і персоналом.

Безпосередньо в кризовий період менеджмент підвищення кваліфікації має бути спрямований на спрощення бюрократичних процедур, спрямування діяльності колективу на позитивне, колегіальне, творче подолання перешкод.

Важливо приділити увагу запобіганню та подоланню конфліктів між працівниками, структурними підрозділами та управлінцями різних рівнів. Натомість актуальним стає посилення відповідальності працівників за виконання власних функцій та функцій організації у цілому

Антикризовий менеджмент підвищення кваліфікації потребує постійного надходження і аналізу інформації щодо стану організації і працівників, перебігу процесів. Тому в період кризи важливо запровадити постійний моніторинг по показниках, які впливають на антикризову стійкість організації.

Як уже було зазначено, криза не лише руйнує, а й дає поштовх до розвитку. Тому в цей період важливо приділити увагу перспективам, розробленню стратегії реалізації можливостей розвитку організації, які відкриває криза.

Найістотніша особливість кризи 2020 р. полягає у повній неможливості провадження аудиторної роботи з усіма категоріями здобувачів освіти, зокрема зі слухачами курсів підвищення кваліфікації. 3 урахуванням зазначеної вище необов'язковості намірів споживачів освітніх послуг ця особливість стає визначальною. На перший план виходить використання можливостей дистанційного навчання як альтернативи традиційним аудиторним заняттям і чи не єдиної можливості провадження освітнього процесу з підвищення кваліфікації.

Користувачі соціальних мереж, представники закладів освіти різних типів і рівнів, громадських організацій, освітніх установ, педагоги, батьки, керівники і самі здобувачі освіти в період карантину активно обговорюють проблему дистанційного навчання. Однією із причин неготовності до нього називають відсутність єдиної для всіх платформи й освітнього контенту.

Охарактеризуємо практичний досвід діяльності з підвищення кваліфікації педагогічних, науковопедагогічних і керівних кадрів освіти в період карантину, що склався в Центральному інституті післядипломної освіти ДЗВО «Університет менеджменту освіти» НАПН України.

Нові реалії освіти в період карантину спонукали колектив ЦІПО ДЗВО «УМО» до пошуків нестандартних рішень щодо організації освітнього процесу і забезпечення якості підвищення кваліфікації педагогічних, науково-педагогічних працівників і керівників освіти. Загрози і виклики як ознаки кризи стали визначальною умовою здобуття нами нового досвіду і відкриття нових можливостей у забезпеченні професійного розвитку фахівців галузі освіти.

Опанувати новий сучасний рівень управління освітнім процесом з підвищення кваліфікації дали змогу інноваційні цифрові технології. Оскільки настання криз є явищем циклічним, ми прогнозували, що на певних етапах будемо стояти перед викликом організації дистанційного навчання. Тому ще у 2019 р. розпочали розроблення й апробацію автентичної платформи, основними вимогами до якої були простота використання, врахування особливостей освіти дорослих, максимальне вивільнення викладачів від технічної роботи, натомість - спрямування їхніх зусиль на створення оригінального, актуального для слухачів контенту. На основі веб-інструментарію mobiSchool була розроблена автентична платформа для підвищення кваліфікації з урахуванням сучасних вимог LMS Adult Learning (LMS AdL). Передбачалося, що на ній буде впроваджено дистанційний етап підвищення кваліфікації за державним замовленням (3 тис. слухачів на рік, державний замовник - НАПН України), а також систему неформального навчання слухачів відповідно до «Порядку підвищення кваліфікації педагогічних і науково-педагогічних працівників», затвердженого постановою Кабінету Міністрів України «Деякі питання підвищення кваліфікації педагогічних і науково-педагогічних працівників» від 21 серпня 2019 р. № 800 зі змінами (Кабінет Міністрів України, 2019).

Для досягнення поставленої мети створено вебсайт «Український відкритий університет 
післядипломної освіти», який включає електронне освітнє середовище для дистанційного навчання.

Науково-педагогічні працівники ЦІПО ДЗВО «УМО» пройшли відповідне навчання і приступили до розроблення контенту підвищення кваліфікації. Дистанційний етап підвищення кваліфікації унормований Положенням про організацію освітнього

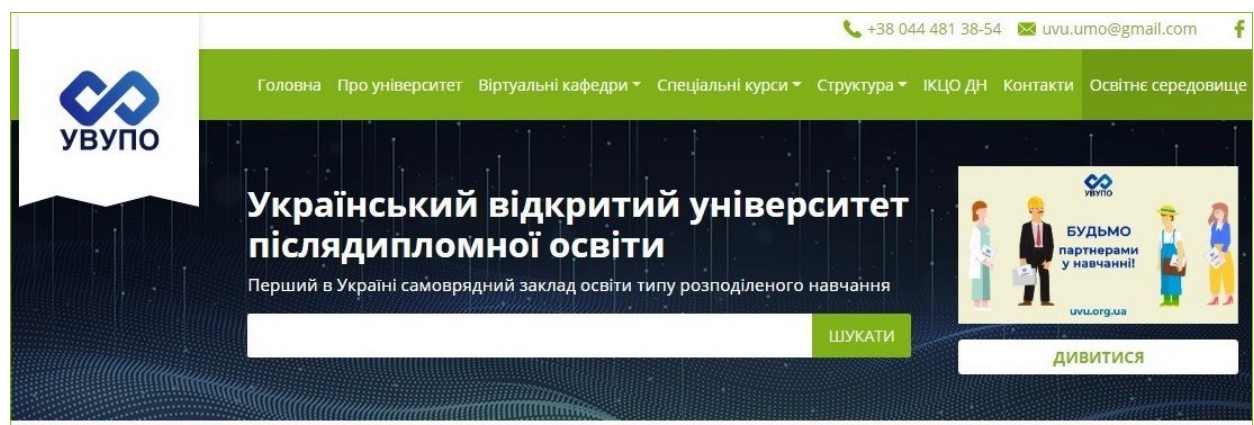

Про університет

український відкритий університет післядипломної освіти є першим в Україні самоврядним (автономним) закладом освіти типу розподіленого університету який, на засадах взаємодії формальної. неформальної та інформальної освіти.

ЧИТАЙТЕ ААЛI
Як стати слухачем

Шановні слухачі, в нашому Університеті Ви отримуете можливість підвищити рівень особистих фахових компетентностей в форматі дистанційного навчання.

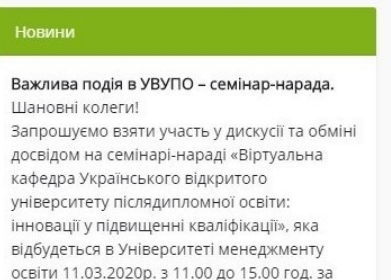

відбудеться в університеті менеджменту процесу у ДЗВО «Університет менеджменту освіти» (2020), затвердженим ученою радою університету в установленому порядку. Відповідно до цього документа зміст створених матеріалів визначається робочим навчальним планом підвищення кваліфікації. Для системи неформальної освіти «Український відкритий університет післядипломної освіти» (далі - УВУПО) розроблено спецкурси, навчальні модулі, окремі теми, зміст яких зорієнтований на актуальні запити споживачів, замовників і стейкхолдерів освітніх послуг з підвищення кваліфікації.

Для забезпечення якості в УВУПО створено віртуальні кафедри: андрагогіки; управління освітою; професійної освіти; психології; цифрових технологій.

у період карантину значно зріс запит на консультації з організації дистанційного навчання та флеш-курси відповідного змісту. Тому до сторінок вебсайту був доданий «Інформаційноконсультаційний центр організації дистанційного навчання».

Наведемо деякі показники з досвіду антикризового менеджменту підвищення кваліфікації у ЦІПО ДЗВО «УМО».

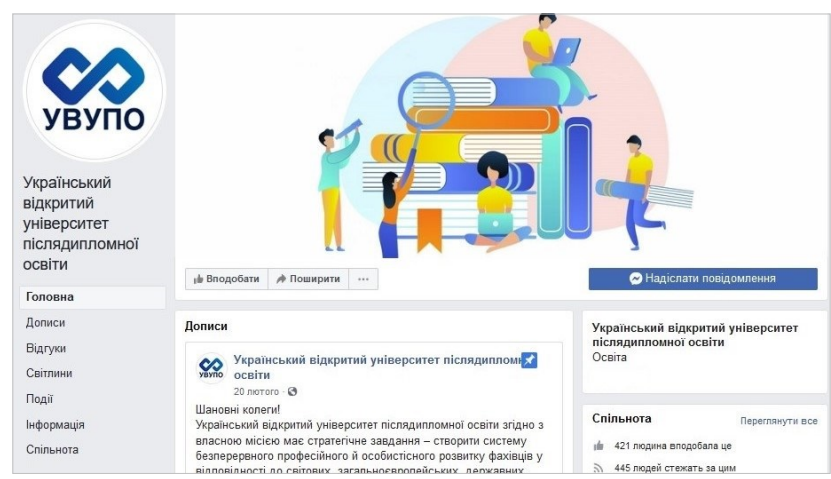

План-графік підвищення кваліфікації відповідно до державного замовлення за період карантину виконано повністю, організовано дистанційне навчання для 27 груп, 556 слухачів із 146 закладів освіти (професійної (професійно-технічної) - 44, загальної середньої - 30, фахової передвищої 20, післядипломної - 15, інших закладів - 13). Слухачами курсів підвищення кваліфікації стали представники 23 областей України та міста Києва. Загалом проведено навчальних занять на віддаленому доступі з використанням ресурсів для проведення відеоконференцій, вебінарів BigBlueButton та JitSi обсягом 790 академічних годин. Освітній процес забезпечено 55 науковопедагогічними працівниками ЦІПО ДЗВО «УМО».

Система неформальної післядипломної освіти ДзВО «УМО» «Український відкритий університет післядипломної освіти» створена і функціонує відповідно до вимог Порядку підвищення кваліфікації педагогічних і науково-педагогічних працівників, затвердженого постановою Кабінету Міністрів України від 21 серпня 2019 р. № 800 зі змінами (Кабінет Міністрів України, 2019).

На короткотривалі курси дистанційного навчання, що пропонують сучасний зміст 3 урахуванням запитів слухачів і замовників освітніх

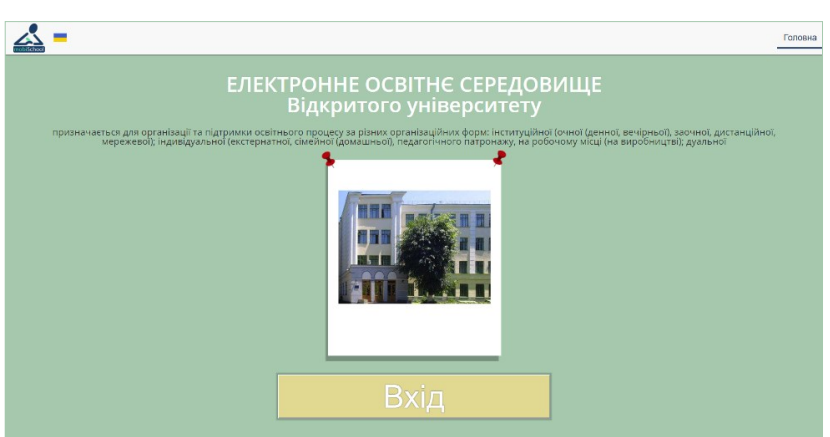


Спецкурс «Основи педагогічної майстерності управляти аудиторією»

Ви дізнаєтесь можливості використання компонентів методики «НОРМА», що дає можливості ефективного управління учнівської/студентської аудиторією. Наведено апробовані інструменти үправління аудиторією, що $є$ обов'язковою передумовою ефективного навчання, системою навичок успішної роботи з учнями/студентами, різноманітними видами діяльності, які забезпечуватимуть найоптимальніші умови навчання.

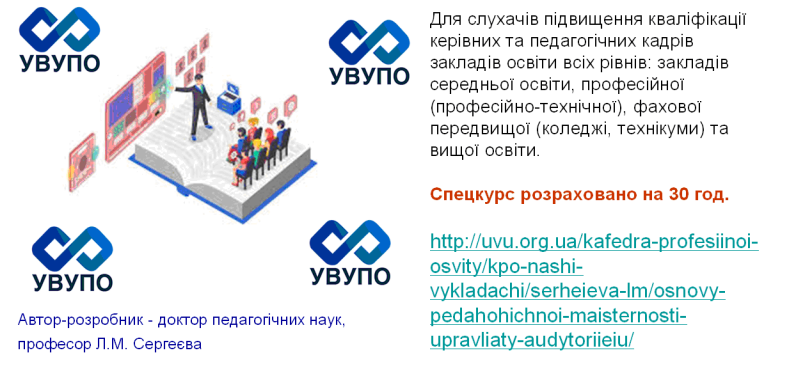

послуг, зареєстровано більш як 400 слухачів, навчаються 72 слухачі, отримали сертифікати 20 слухачів. Для них розроблено 31 спецкурс.

Для забезпечення дистанційного навчання слухачів на курсах підвищення кваліфікації створено і розміщено в освітньому середовищі:

- ЦІПО: 89 електронних кабінетів викладачів, розміщено 292 матеріали у веб-бібліотеці;

- УВУПО: 12 електронних кабінетів викладачів, розміщено 64 матеріали у веб-бібліотеці.

Дистанційно проведено спрямовані на професійний розвиток педагогів методичні заходи: 57 вебінарів і конференцій (1436 учасників); 328 консультацій.

Важливим чинником подолання кризи ми вважаємо комунікацію в соціальних мережах зі слухачами, всіма освітянами і їх спільнотами. Наразі охоплена нами віртуальна аудиторія становить 39255 користувачів.

Варто констатувати, що криза виявила нові можливості підвищення кваліфікації, якими скористався колектив ЦПО ДЗВО «УМО».

Отже, можемо узагальнити ключові напрями і рекомендації щодо антикризового менеджменту системи підвищення кваліфікації.

Підтримка педагогічної системи підвищення кваліфікації, її відкритість, чітка координація діяльності різних структурних підрозділів, орієнтація на спільний результат, зрозумілий кожному шлях його досягнення значно посилюють конкурентоздатність в умовах кризи.

Менеджер освіти для подолання кризи або зменшення їі наслідків має не лише розробити антикризову програму, а й подбати про те, щоб уже зараз, у цей важкий час, було оновлену стратегію подальшого розвитку системи підвищення кваліфікації. Адже варто пам'ятати, що криза обмежує існуючі можливості, проте відкриває нові.
Щоб обрати оптимальні методи антикризового менеджменту, слід зважити, як вони співвідносяться із засадничими принципами підвищення кваліфікації, а потім визначити, які саме організаційні, стратегічні або управлінські перешкоди заважають їхньому застосуванню. Досвід показує, що в кожній конкретній ситуації достатньо віднайти поєднання двох-чотирьох методів управління, які будуть найбільш ефективними «тут і зараз».

Отже, криза - це не лише загроза, а й невикористана можливість. Реалізувати ії на засадах антикризового менеджменту означає посилити конкурентоспроможність освітніх послуг із підвищення кваліфікації.

\section{СПИСОК ВИКОРИСТАНИХ ДЖЕРЕЛ}

Акофф, Р., Магидсон, Дж., \& Эддисон, Г. (2007). Идеализированное проектирование. Как предотвратить завтрашний кризис сегодня. Создание будущего организации (Ф.П. Тарасенко, пер.). Дніпро: Баланс Бизнес Букс.

Державний заклад вищої освіти «Університет менеджменту освіти» НАПН України. (n.d.). Головна. http://umo.edu.ua/

Державний заклад вищої освіти «Університет менеджменту освіти» НАПН України. (2020, 28 лютого). Положення про організацію освітнього процесу у ДзВО «Університет менеджменту освіти» (01-01/139). https://bit.ly/2zJTM31

зубарєва, М.А. (2014). Прикладні антикризові PRтехнології : навчальний посібник. Острог: Видавництво Національного університету «Острозька академія».

Кабінет Міністрів України. (2019, 21 серпня). Деякі питання підвищення кваліфікації педагогічних $і$ науково-педагогічних працівників (800). https:// zakon.rada.gov.ua/laws/show/800-2019-п

Кабінет Міністрів України. (2020, 11 березня). Про запобігання поширенню на території України гострої респіраторної хвороби COVID-19, спричиненої коронавірусом SARS-CoV-2 (211). https:// zakon.rada.gov.ua/laws/show/211-2020-п

Сорочан, Т.М. (2009а). Антикризові поради керівникові навчального закладу. Управління освітою, (11), 35. http://lib.iitta.gov.ua/703968/

Сорочан, Т.М. (2009b). Антикризовий менеджмент загальноосвітнього навчального закладу. Директор школи, ліцею, гімназії, (3), 108-111. http:// lib.iitta.gov.ua/703969/

Український відкритий університет післядипломної освіти. (n.d.). Головна. http://uvu.org.ua/

Український відкритий університет післядипломної освіти. (n.d.). Електронне освітнє середовище для дистанційного навчання. http://uvupo.ues.net.ua/ index.php/ua/

Хіт, Р. (2002). Кризовий менеджмент для керівників (Р.Л. Ткачук, С.М. Рябчук, Н.І. Мішеніна, пер.). Київ: Всеувито, Наукова думка. 


\title{
CRISIS MANAGEMENT IN THE IN-SERVICE TRAINING
}

\author{
Liubov Kartashova \\ DSc in Pedagogy, Professor, Deputy Director, Central Institute of Postgraduate Education \\ at the State Higher Education Institution "University of Educational Management", \\ National Academy of Educational Sciences of Ukraine, Kyiv, Ukraine \\ Mykola Kyrychenko \\ PhD in Pedagogy, Associate Professor, Rector, State Higher Education Institution "University of \\ Educational Management", National Academy of Educational Sciences of Ukraine, Kyiv, Ukraine \\ Tamara Sorochan \\ DSc in Pedagogy, Professor, Director, Central Institute of Postgraduate Education \\ at the State Higher Education Institution "University of Educational Management", \\ National Academy of Educational Sciences of Ukraine, Kyiv, Ukraine
}

Abstract. The paper enlightens the problem of managing the listeners' distance in-service learning during the crisis exemplified by the Central Institute of Postgraduate Education at the State Higher Education Institution "University of Educational Management", National Academy of Educational Sciences of Ukraine. The crisis is characterised as a sharp change in the state of affairs, break, aggravation of the situation, critical detection of contradictions in the socioeconomic system or a separate organisation, which threatens its stability in the environment and makes it impossible to perform functions normally. The peculiarities of the in-service training system functioning under the quarantine are summarised. The "crisis management" is defined as managing a certain system in a state of imbalance. The practical experience of in-service teacher training at the Central Institute of Postgraduate Education is described. The crisis management of the non-formal education system "The Ukrainian Open University of Postgraduate Education" is presented, in particular creation of virtual departments, education content development practice, focused on the current demands of consumers, customers and stakeholders of in-service training services. The recommendations concerning distance learning organisation at the in-service training courses during the crisis are given.

Keywords: in-service training; distance learning; crisis; crisis management; virtual departments.

Дата публікації: 19 травня 2020 р. 